\title{
MULTICRITERIA ANALYSIS OF MUNICIPAL SOLID WASTES ENERGY RECOVERY TECHNOLOGIES IN GREECE
}

\author{
E. KONDILI ${ }^{1}$ \\ I. BARTZIS ${ }^{2}$ \\ M. KAPSALI ${ }^{2}$ \\ J.K. KALDELLIS ${ }^{2, *}$
}

Received: 05/12/11

Accepted: 09/03/12

\author{
${ }^{1}$ Optimisation of Production Systems Laboratory, TEI of Piraeus \\ P.O. Box 41046, Athens 12201, Greece \\ ${ }^{2}$ Laboratory of Soft Energy Applications \& Environmental Protection \\ TEl of Piraeus, P.O. Box 41046, Athens 12201, Greece
}

*to whom all correspondence should be addressed: e-mail: jkald@teipir.gr

\section{ABSTRACT}

Municipal Solid Waste (MSW) management is the field of science which explores and evolves strategies minimizing the final amount of wastes delivered to landfills and reducing the corresponding pollution related to all stages of treatment and collection. In the best practices of MSW the inherent energy of wastes is being recovered. In this study, the most appropriate energy recovery methods utilizing MSW for Greece (i.e. Sorting plant at landfill site with biogas recovery and RDF production, Incineration of MSW with small pre-treatment and Controlled landfill site with biogas recovery) are investigated based on the composition of wastes, the compatibility of the methods with the EU legislation, their technical availability, energy recovery capacity and contribution to the national energy balance, as well as economic issues, the maturity of the technologies involved and the land occupation requirements. A detailed multi-criteria analysis is applied considering the expected MSW production of Greece until 2020 along with different scenarios of waste utilization. Based on the results obtained, as well as on the elaboration of a sensitivity analysis, the "Controlled landfill" method is designated as the most prevalent energy recovery method for Greece, although under specific prioritization of the main parameters involved, the "Incineration" may be equally appropriate as well.

KEYWORDS: energy recovery from MSW, Waste-to-Energy plants, incineration of MSW, sorting plant at landfill site, controlled landfill sites.

\section{INTRODUCTION}

The increment of Municipal Solid Wastes (MSW) production worldwide in association with the continuously growing concentration of chemical components in the wastes (Mahar et al., 2009) and the storage problems involved, have indicated the need for the implementation of more effective MSW treatment strategies (Sakkas et al., 2005; Konstantinidis et al., 2000). Furthermore, in the best MSW management practice, a considerable percentage of the energy consumed during the manufacturing process of the products (Cherubini et al., 2008) may be retrieved and exploited. The energy output of such installations is considered as a Renewable Energy Source (RES) and contributes to the conservation of natural resources, reduces the needs for new conventional power stations and provides security of energy supply (Cheng and $\mathrm{Hu}, 2010$ ), while a new market is being created amid an international economic crisis. Furthermore, the final amount of wastes delivered to landfills is minimized and the corresponding pollution related to all stages of treatment is significantly reduced (Dolgen et al., 2005; Haley, 1990). In this context, the selection of the appropriate strategy for energy recovery by the utilization of MSW depends mostly on the quantity and composition of wastes, the moisture content, the current legislation, geopolitical and climate conditions, the ease of MSW transportation, the exploitation of the products downstream the processes, the initial and operational cost of the plants, the energy balance of each country and the mass and energy balance of the methods adopted (Cherubini et al., 2008; Cherubini et al., 2009; Consogni et al., 2005). 
In Greece, between 1990 and 2007, solid waste generation presented a continuous annual increase, i.e. from $3 \mathrm{Mt}$ to $5 \mathrm{Mt}$, while the per capita solid waste generated quantities grew from $0.82 \mathrm{~kg} \mathrm{cap}^{-1}$ day $^{-1}$ to $1.21 \mathrm{~kg} \mathrm{cap}^{-1} \mathrm{day}^{-1}$ during the same period (MINENV, 2010). At that period however, no energy recovery activities have been implemented so far for one of the three main options of MSW management, i.e. recycling, mechanical and biological treatment (MBT) (Konstantinidis et al., 2001; 2003), with almost $90 \%$ of the wastes being directed to landfills (HSWMA, 2010). In fact, there are still 200-300 unmanaged illegal landfills operating in Greece each one facing a penalty of $34,000 €$ day $^{-1}$, which is imposed to the State due to infringement of the EU Landfill Directive. However, among the national policies and fundamental objectives for the waste sector the next few years is the elimination of unmanaged solid waste disposal sites as well as the application of "material recovery at the source". According to the Joint Ministerial Decision 29407/3508 in accordance to EU Directive 99/31, the quantities of MSW which may need additional treatment will significantly increase after 2013. In this context, Figure 1 illustrates data regarding the required treatment of all MSW produced in the mainland of Greece and the island of Crete (i.e. the biggest island of Greece) until 2020. More specifically, one may obtain the MSW quantities that are required to be landfilled, recycled and treated as well as the urgent need for the creation of additional MSW treatment facilities. At this point, one should keep in mind that the energy dependency (i.e. imports divided by gross national energy consumption) of Greece is rather high (Chalvatzis and Hooper, 2009), reaching about $70 \%$ at the moment. Therefore, investments in MSW treatment should be associated with the recovery of the embedded energy of wastes (Europe's Energy Portal, 2010).

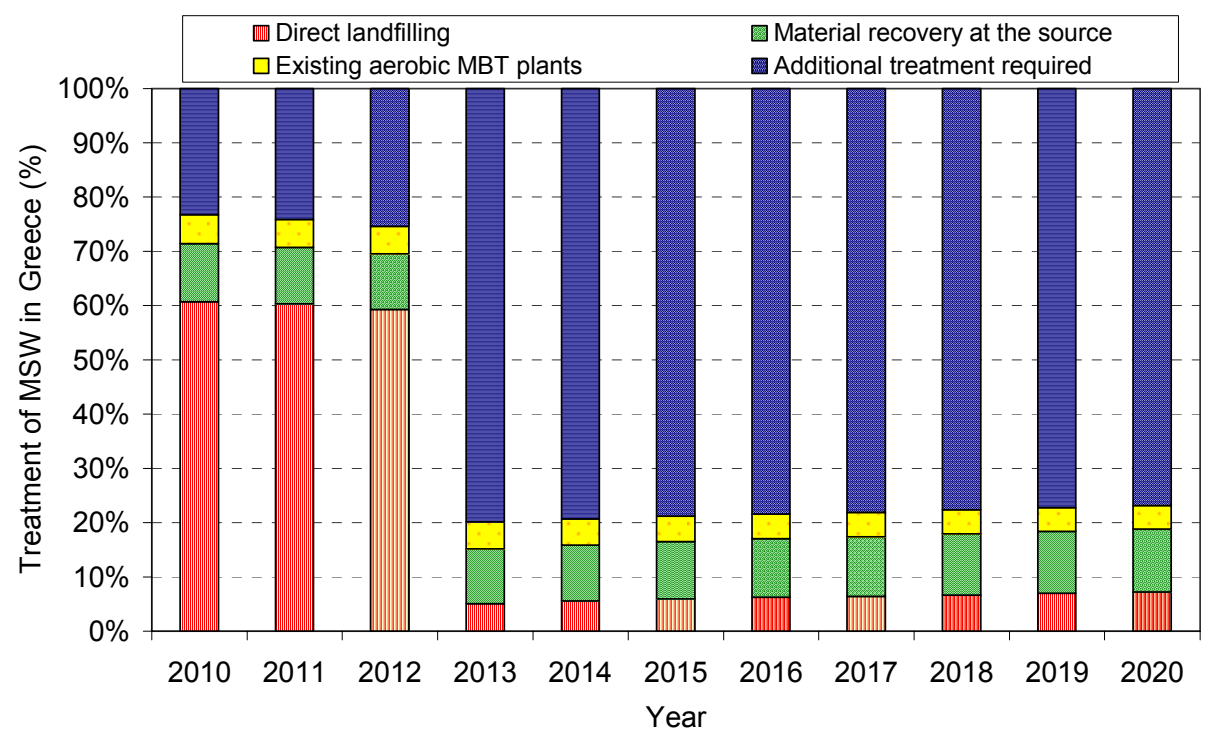

Figure1. Treatment of MSW in the mainland of Greece and the island of Crete until 2020 (based on data from (Economopoulos, 2009))

Considering the above and taking into account the related stipulations of the EU legislation (Directives 1999/31, 2004/12 and 2008/98) as well as the effective absorbance of the potential installations by-products by the local market, the most appropriate energy recovery methods utilizing MSW for Greece are considered to be the following:

- Sorting plant at landfill site for the recovery of useful material, the production of Refused Derived Fuel (RDF) by the rest inorganic fraction and the biogas recovery by the anaerobic digestion of the organic fraction. The energy recovery of this method is considered as the sum of electricity production by the provision of biogas in gas turbines and the incineration of RDF on site.

- Incineration of MSW with small pre-treatment in order to partially remove the useful materials and moisture and the co-combustion of MSW with fossil fuels in excess of oxygen. Steam turbines produce electricity on site.

- Controlled landfill site with biogas recovery which is actually a bottom isolated area with a horizontal and a vertical piping system for the collection of the liquid sludge and the biogas production respectively. The biogas is directed to the on site electricity producing gas turbines.

It should be mentioned that the electrical/thermal energy production of WTE (Waste-to-Energy) 
plants and the biogas deriving by the digestion of wastes can be easily provided to the consumers, while on the contrary, the production of RDF and SRF (Solid Recovered Fuel) usually meets the needs of the local cement industry which uses these by-products to feed its furnaces (Consogni et al., 2005). More specifically, the utilization of RDF for electricity generation comprises a questionable issue due to the possibility of operational malfunctions in the incinerators by the presence of fusible material. Therefore, the most popular destination of RDF is the cement-industry furnaces which, in the case of Greece, may theoretically reach a total capacity of $250,000 t$ of RDF per year (Economopoulos, 2009).

\section{POSITION OF THE PROBLEM}

The basic idea currently examined is the utilization of the MSW leftovers after the implementation of EU directives regarding material recovery, recycling and hierarchy of the MSW treatment, by taking advantage of the central road and railroad network in the Greek mainland and the island of Crete, in order to achieve economies of scale, cost effective facilities and convenient distribution of the byproducts. Note that the MSW production by the numerous Greek islands is exempted due to the individual small quantities and the complexity of the existing naval transportation system which discourage the delivery of wastes to central treatment sites.

In this context, a detailed multi-criteria analysis is applied for the three selected energy recovery methods utilizing MSW, considering five different scenarios of waste utilization (between $20 \%$ and $100 \%$ ) within a waste production safety margin of $\pm 10 \%$.

As already mentioned, the three methods under evaluation are:

- Sorting plant at landfill site

- Incineration of MSW

- Controlled landfill site

It should be noted that the expected evolution of MSW production corresponds to the "Business-asUsual" scenario (BAU), the $-10 \%$ to the "Minimum" scenario while the $+10 \%$ to the "Maximum" MSW evolution scenario. Table 1 includes the resulted variable parameters from the multi-criteria analysis for the three energy recovery methods within a range of the lowest MSW utilization scenario of $20 \%$ with a $-10 \%$ variation, to the highest MSW utilization scenario of $100 \%$ with $+10 \%$ variation estimated for the time series 2008-2020. The assessment of these estimations is based on some fundamental assumptions/projections regarding the following main points:

- After the implementation of EU Directive 2004/12, which stipulates the partial recycling of the inorganic fraction of wastes, the ingredient and final quantities of MSW in Greece are expected to be as illustrated in Figure 2. The presented final quantities are considered as the input of the potential energy recovery installations where an additional partial removal/separation of inorganic fraction is taking place. It should be mentioned that, according to EU Directive 1999/31, for the case of controlled landfill sites, the bio-degradable fraction of the MSW delivered must be reduced by 2013 to $50 \%$ of these that were landfilled during 1995 . To this end, the final quantities delivered to controlled landfill sites after 2013 are reduced by almost $70 \mathrm{~kg} / \mathrm{cap} / \mathrm{year}$ of bio-degradable material, while the biogas production per tonne of MSW treated is assumed to be the half of the initial for the years 2013-2020.

- The Greek energy balance forecasts until 2020 which affect the "Fossil fuel substitution" and the "RES contribution" values are assessed under the assumption that the augmentative rates of the final energy consumption of electricity (approx. $4 \%$ ) and the electricity generation based on fossil fuels (approx. $3 \%$ ) in Greece for the period 1997-2008 (Eurostat, 2009) shall remain stable until 2020. The electricity imports/exports of the country (Kaldellis et al., 2009; 2011) as well as the distribution losses are taken into account, while the RES target of Greece in electricity production by 2020 is set at $20.1 \%$ as a benchmark in an attempt to give the order of magnitude of the contribution of these energy recovery methods in the national fuel mix in terms of 2010.

- All economic indicators related to every individual energy recovery method are determined based on public documents and scientific studies (see for example Defra, 2007; PPC, 2010; Economopoulos, 2007; The World Bank, 2005; Couth et al., 2003). 
Table 1. Variables of the multi-criteria analysis for the three energy recovery methods

(Economopoulos, 2007; EC, 2008; World Bank, 2005; Cherubini et al., 2009)

\begin{tabular}{|c|c|c|c|c|c|c|c|c|c|c|}
\hline $\begin{array}{l}\text { Energy } \\
\text { recovery } \\
\text { method }\end{array}$ & 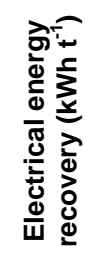 & 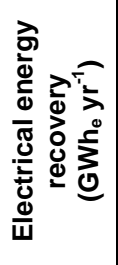 & 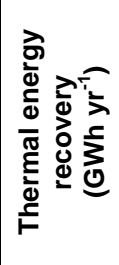 & 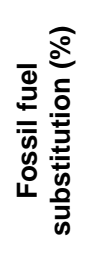 & 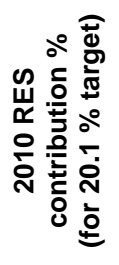 & 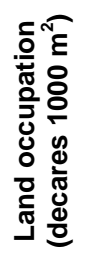 & 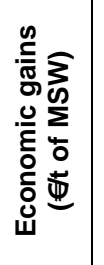 & 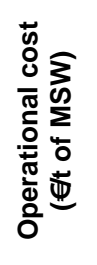 & & 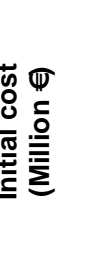 \\
\hline \multirow{3}{*}{$\begin{array}{l}\text { SORTING } \\
\text { PLANT AT } \\
\text { LANDFILL } \\
\text { SITE }\end{array}$} & \multirow{3}{*}{$\begin{array}{l}\infty \\
\text { o }\end{array}$} & \multirow{2}{*}{ ষ্ল } & & \multirow{2}{*}{$\stackrel{\mathscr{P}}{\circ}$} & \multirow{2}{*}{$\stackrel{\rho}{r}$} & \multirow{3}{*}{$\stackrel{\dddot{m}}{\leftarrow}$} & \multicolumn{2}{|c|}{$\begin{array}{l}f o r>50,000 \\
\text { t/yr capacity }\end{array}$} & \multirow[b]{3}{*}{ ్ㅗ․ } & \multirow{3}{*}{ 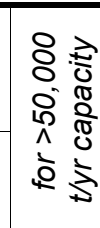 } \\
\hline & & & & & & & \multirow[b]{2}{*}{ ๗ } & \multirow[b]{2}{*}{$\stackrel{\mathscr{N}}{N}$} & & \\
\hline & & 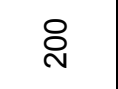 & & 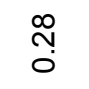 & $\stackrel{\sim}{\sim}$ & & & & & \\
\hline \multirow{3}{*}{$\begin{array}{l}\text { INCINERAT } \\
\text { ION OF } \\
\text { MSW }\end{array}$} & \multirow{3}{*}{ 号 } & \multirow{2}{*}{ 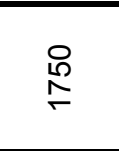 } & \multirow{2}{*}{ 怘 } & \multirow{2}{*}{ i⿱ } & \multirow{2}{*}{$\stackrel{N}{\check{L}}$} & \multirow{2}{*}{$\stackrel{\mathscr{O}}{\circ}$} & \multicolumn{2}{|c|}{$\begin{array}{l}\text { for } 450,000 \\
\text { t/yr capacity }\end{array}$} & 号 & \multirow{3}{*}{ 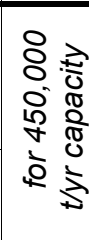 } \\
\hline & & & & & & & \multirow{2}{*}{ க } & \multirow{2}{*}{ ని } & & \\
\hline & & $\stackrel{O}{N}$ & 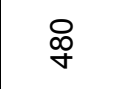 & $\ddot{0} n$ & $\stackrel{\nabla}{\leftarrow}$ & 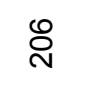 & & & ণ্లి & \\
\hline \multirow{2}{*}{$\begin{array}{l}\text { CONTROL } \\
\text { LED } \\
\text { LANDFILL } \\
\text { SITE }\end{array}$} & \multirow{2}{*}{ 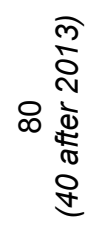 } & 온 & & 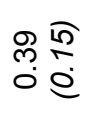 & 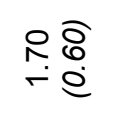 & ○ & \multirow{2}{*}{ 우 } & \multirow[b]{2}{*}{$\bar{N}$} & & $\stackrel{\sim}{N}$ \\
\hline & & 월 & & 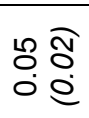 & ๗ָำ & ᄋ्ల & & & & 0 \\
\hline
\end{tabular}

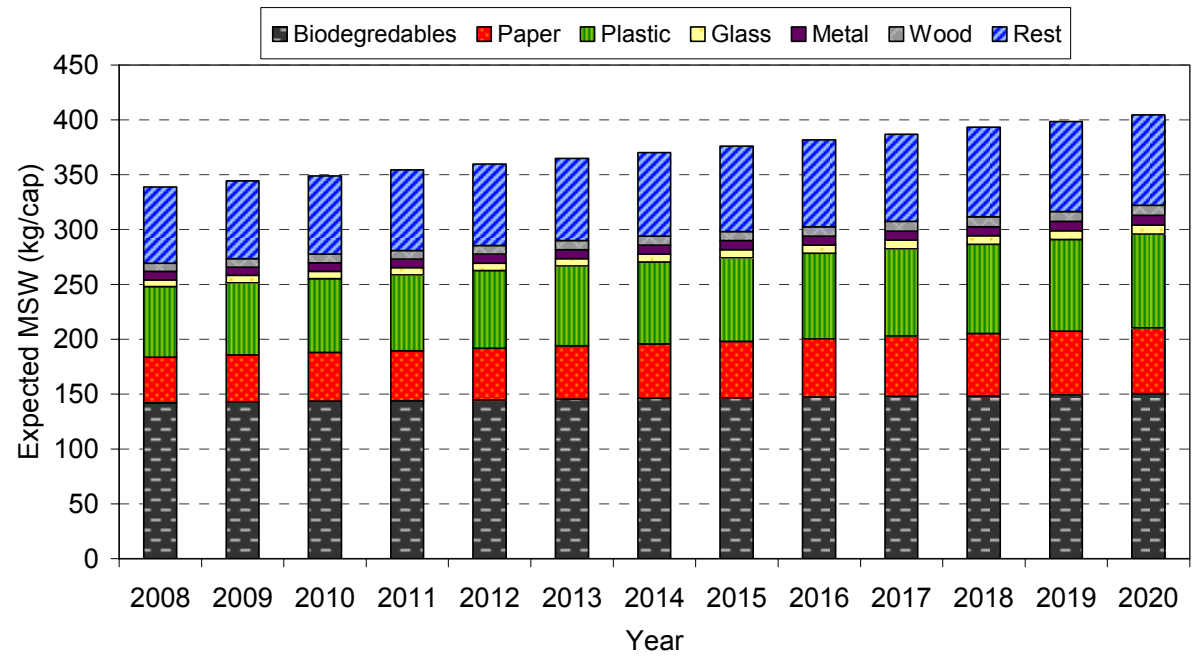

Figure 2. The expected ingredient and final quantities of MSW in Greece after the imposition of the EU Directives (based on data from EU Directive 2004/12 and Economopoulos, 2009)

- The land occupation requirements are based on international literature estimations (CEWEP, 2009; HSWMA, 2010), while other parameters such as the MSW utilization scenarios assessed and the leftovers downstream each individual energy recovery method (i.e. parameters that affect the determination of land occupation) are also taken into account for the purpose of the current study.

- According to the 2008/98 EU Directive the energy production by the incineration of MSW is considered as "recovery" in the hierarchy of the MSW treatment methods under the condition that the thermal energy production of the plant is used in external purposes other than the pre- 
treatment of wastes and internal consumption of the facilities. This aims to the overall enhancement of the plant's efficiency over $65 \%$ for the facilities permitted after 31 December 2008 (2008/98 EU Directive, Annex II). In MSW incineration plants with annual capacity 450,000 t per year and using oil as a supplementary fuel for the combustion, the overall efficiency reaches $68 \%$, while even the oldest waste incinerators have the ability to recover electricity to thermal energy with a proportion 1:2 (CEWEP, 2009).

Following, based on the variable parameters of the multi-criteria analysis, a quantitative evaluation method of the three energy recovery technologies is carried out. The main parameters involved are normalized, while realistic weight factors are introduced for extracting evaluation grades for each energy recovery method examined. Accordingly, the prospects of the specific quantitative evaluation method are thoroughly investigated by carrying out a sensitivity analysis based on the variance of the incorporated parameter values.

\section{METHODOLOGY}

The method being used in the work is the classical weighted sum Multicriteria Analysis. In this simple multi-objective optimisation method, a set of criteria is escalated into a single objective by multiplying each criterion with a user supplied weight being determined by its relative importance. The steps of the methodology followed are analyzed below:

Step 1: MSW potential quantities in the Greek mainland and the island of Crete until 2020 are designated within a safety production margin of $\pm 10 \%$ and five different waste utilization scenarios are assessed (from $20 \%$ to $100 \%$ ).

Step 2: A multi-criteria analysis is performed for every energy recovery method and MSW utilization scenario (see for example Table 1).

Step 3: The value of the following parameters is determined.

- Initial capital investment, i.e. the capital required for the construction of the facilities.

- Net gains per tonne of MSW treated, i.e. the economic gains minus the operational cost per tonne of waste treated.

- Fossil fuel substitution, i.e. the fossil fuel percentage intended to be substituted by the examined technologies in the electricity sector (environmental impacts reduction).

- RES contribution, i.e. the contribution percentage of the energy recovery methods to the national $20.1 \%$ RES target of Greece (energy supply security improvement).

- Land occupation, i.e. the land requirements for the deposition of the residues downstream the energy recovery processes.

Step 4: The gap between the lowest and the highest value of the parameters illustrated in Table 1 is divided in a scale of 1000 points. The least wanted values take zero (0) grades while the most wanted ones take 1000 grades. For example, in the "land occupation" parameter the more land is required the less grades are attributed. For conformity reasons the lowest values of the parameters are assumed to be zero (0) while the highest values are selected to be slightly over the real higher values in case any other energy recovery method performs wider limits in the future. The normalization process is illustrated in Table 2. Following, Table 3 shows the normalized grades of the parameters for the three energy recovery methods for two different MSW utilization scenarios (i.e. $20 \%$ and $100 \%$ ) estimated for a representative year (i.e. 2015). Note that, the "Sorting plant at landfill site" energy recovery method is not recommended for a scenario of more than $20 \% \mathrm{MSW}$ utilization due to the resulting repletion of the local market by RDF (Economopoulos, 2009) which is the main by-product of the specific technology. According to Table 2, the "Fossil fuel substitution" parameter values are limited between 0 (zero marks) and 2.5 (1000 marks). Therefore, in the $20 \%$ utilization scenario the fossil fuel percentages of $0.344,0.408$ and 0.025 stand for 138,162 and 10 marks respectively (Table 3 ). Accordingly, the "Land occupation" parameter values are limited between 0 (1000 marks) and 5000 (zero marks). Therefore, in the same utilization scenario the 134 decares (i.e. $134,000 \mathrm{~m}^{2}$ ) take 973 marks, the 206 decares take 959 marks and the 1030 decares take 794 marks. 
Table 2. Normalization and marking range of the parameters

\begin{tabular}{l|c|c|c|c|c|c}
\hline & $\begin{array}{c}\text { Minimum } \\
\text { value }\end{array}$ & $\begin{array}{c}\text { Grade of } \\
\text { minimum } \\
\text { values }\end{array}$ & $\begin{array}{c}\text { Maximum } \\
\text { Value }\end{array}$ & $\begin{array}{c}\text { Grade of } \\
\text { maximum } \\
\text { values }\end{array}$ & Scale & Step \\
\hline $\begin{array}{l}\text { 1. Initial capital investment } \\
\text { (million } € \text { ) }\end{array}$ & 0 & 1000 & 2500 & 0 & 1000 & 2.5 \\
\hline 2. Net gains $€ \mathbf{t}^{-1}$ of MSW & 0 & 0 & 25 & 1000 & 1000 & 0.025 \\
\hline 3. Fossil fuel substitution (\%) & 0 & 0 & 2.5 & 1000 & 1000 & 0.0025 \\
\hline 4. RES contribution (\%) & 0 & 0 & 20 & 1000 & 1000 & 0.02 \\
\hline 5. Land occupation (decares) & 0 & 1000 & 5000 & 0 & 1000 & 5 \\
\hline
\end{tabular}

Table 3. Normalized grades for the Business-as-Usual (BAU) evolution of MSW quantities for the $20 \%$ and $100 \%$ MSW utilization scenario (for 2015)

\begin{tabular}{|c|c|c|c|c|c|c|c|c|}
\hline BAU & $\mathrm{i}$ & PARAMETER & $\begin{array}{l}\text { SORTING } \\
\text { PLANT AT } \\
\text { LANDFILL } \\
\text { SITE }\end{array}$ & 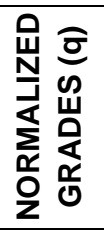 & $\begin{array}{l}\text { INCINERATION } \\
\text { OF MSW }\end{array}$ & 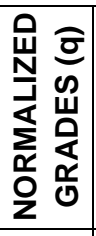 & $\begin{array}{l}\text { CONTROLLED } \\
\text { LANDFILL } \\
\text { SITE }\end{array}$ & 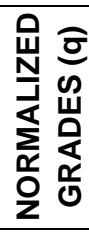 \\
\hline \multirow{5}{*}{$20 \%$} & 1 & $\begin{array}{l}\text { Initial capital } \\
\text { investment } \\
\text { (million } € \text { ) }\end{array}$ & 151.1 & 940 & 395.1 & 842 & 2.825 & 999 \\
\hline & 2 & $\begin{array}{l}\text { Net gains of } \\
M S W\left(€ t^{-1}\right)\end{array}$ & 7.18 & 287 & 11 & 456 & 19.9 & 795 \\
\hline & 3 & $\begin{array}{l}\text { Fossil fuel } \\
\text { substitution } \\
(\%)\end{array}$ & 0.344 & 138 & 0.408 & 162 & 0.025 & 10 \\
\hline & 4 & $\begin{array}{l}\text { RES } \\
\text { contribution } \\
(\%)\end{array}$ & 1.465 & 73 & 1.728 & 86 & 0.105 & 5 \\
\hline & 5 & $\begin{array}{l}\text { Land } \\
\text { occupation } \\
(\text { decares= } \\
\left.1000 \mathrm{~m}^{2}\right)\end{array}$ & 134 & 973 & 206 & 959 & 1030 & 794 \\
\hline \multirow{5}{*}{$100 \%$} & 1 & $\begin{array}{l}\text { Initial capital } \\
\text { investment } \\
\text { (million } € \text { ) }\end{array}$ & $\begin{array}{c}\text { Not } \\
\text { applicable }\end{array}$ & - & 1975.7 & 210 & 15.7 & 994 \\
\hline & 2 & $\begin{array}{l}\text { Net gains of } \\
M S W\left(€ t^{-1}\right)\end{array}$ & $\begin{array}{c}\text { Not } \\
\text { applicable }\end{array}$ & - & 11 & 456 & 19.9 & 795 \\
\hline & 3 & $\begin{array}{l}\text { Fossil fuel } \\
\text { substitution } \\
(\%)\end{array}$ & $\begin{array}{c}\text { Not } \\
\text { applicable }\end{array}$ & - & 2.03 & 812 & 0.138 & 55 \\
\hline & 4 & $\begin{array}{l}\text { RES } \\
\text { contribution } \\
(\%)\end{array}$ & $\begin{array}{c}\text { Not } \\
\text { applicable }\end{array}$ & - & 8.641 & 432 & 0.586 & 29 \\
\hline & 5 & $\begin{array}{l}\text { Land } \\
\text { occupation } \\
(\text { decares= } \\
\left.1000 \mathrm{~m}^{2}\right)\end{array}$ & $\begin{array}{c}\text { Not } \\
\text { applicable }\end{array}$ & - & 1030 & 794 & 5000 & 0 \\
\hline
\end{tabular}


Step 5: Finally, the evaluation grades of the three energy recovery methods are estimated as follows:

$$
\text { Evaluation grade }=\Sigma q_{i} w_{i}
$$

where " $q$ " is the normalized grade of an energy recovery method (see Table 3 ) for a specific MSW utilization scenario and " $w_{i}$ " is the corresponding weight factor within a range of $0-1$.

\section{RESULTS}

\section{Reference case}

After the implementation of the aforementioned steps the effectiveness of the three energy recovery methods utilizing MSW (i.e. "Sorting plant at landfill site with biogas recovery and RDF production", "Incineration of MSW with small pre-treatment" and "Controlled landfill site with biogas recovery") is evaluated, considering the expected MSW production in the Greek mainland and the island of Crete until 2020 along with different scenarios of waste utilization. In this context, Figure 3 shows the ranking of the three energy recovery methods for the representative year of 2015. The weight factor values used and the selection criteria considered in that case are given in Table 4. Based on the results obtained, it becomes obvious that the prevalent energy recovery method utilizing MSW in the concerned Greek regions is the "Controlled landfill site" mainly due to the "Initial cost" parameter which performs very high normalized grades in this case (see also Table 3), having at the same time the higher weight factor value (i.e. $40 \%$ ).

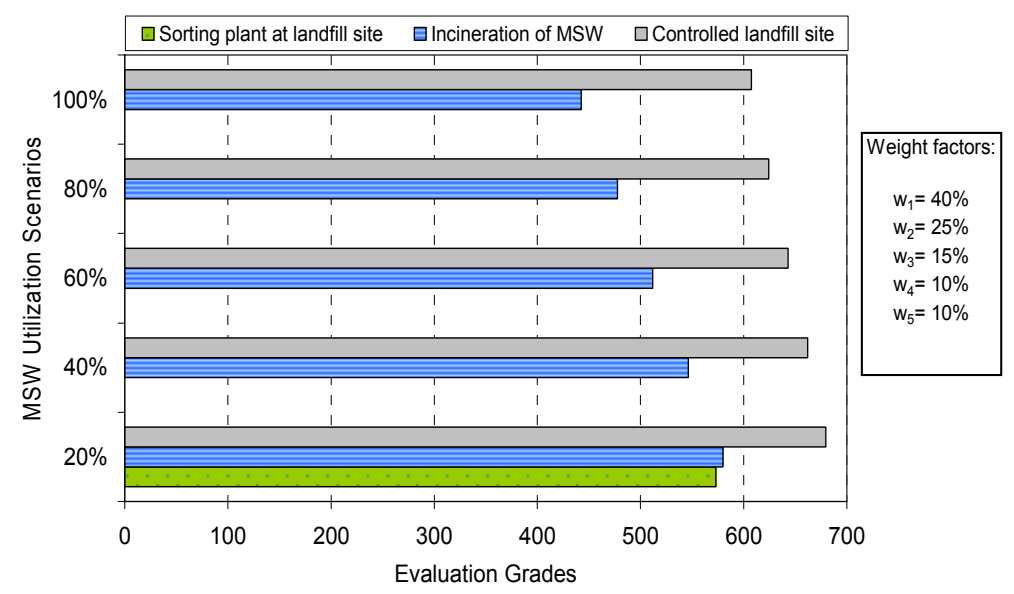

Figure 3. Evaluation of the three energy recovery methods (for 2015 and BAU case)

Table 4. Selection criteria of the reference weight factor values

\begin{tabular}{|c|c|}
\hline $\begin{array}{l}\text { Weight } \\
\text { factor } \\
\text { value }\end{array}$ & Criterion of selection \\
\hline $\mathrm{w}_{1}=0.40$ & $\begin{array}{r}\text { due to the importance of the "initial capital" parameter under the present } \\
\text { economic crisis }\end{array}$ \\
\hline$w_{2}=0.25$ & due to our interest for a relatively lucrative investment \\
\hline $\mathrm{w}_{3}=0.15$ & $\begin{array}{l}\text { due to the importance of the energy independency of the country and } \\
\text { geopolitical and environmental reasons }\end{array}$ \\
\hline $\mathrm{w}_{4}=0.10$ & $\begin{array}{l}\text { because of the great wind and solar potential of the country which is expected } \\
\text { to attract a large share of the domestic investments in RES }\end{array}$ \\
\hline$w_{5}=0.10$ & $\begin{array}{c}\text { because the complex terrain of Greece could easily accommodate Waste-to- } \\
\text { Energy (WTE) plants without much aesthetic and social cost }\end{array}$ \\
\hline
\end{tabular}

\section{The ability of an alternative planning in energy recovery by MSW}

As mentioned above, the quantitative evaluation method presented provides the ability of different planning in energy recovery by MSW, thus making the selection of the weight factor values critical. In this context, Figure 4 shows an alternative scenario which is focused on the "Fossil fuel substitution" parameter by the energy recovered from the MSW utilization. This is achieved through the diversification of the corresponding weight factor by doubling its value (i.e. from $15 \%$ to $30 \%$ ), 
while the hierarchy of the other parameters has also been changed as well. Thus, the dominant parameter is now considered the "Fossil fuel substitution", while the "Initial cost" and "Land occupation" come second (with $w_{1}, w_{5}$ being equal to $25 \%$ ), the "Net gains" follow (with $w_{2}$ being equal to $15 \%$ ) and the "RES contribution" is almost out of interest (with $w_{4}$ being equal to $5 \%$ ).

Proceeding to the results obtained, one may realize from Figure 4 that for the depicted weight factors, the dominant energy recovery method to be applied in the concerned Greek regions is the "Incineration" for MSW utilization scenarios ranging from $40 \%$ to $100 \%$, while in case of $20 \%$ waste utilization there are not any considerable differences between the three methods under examination.

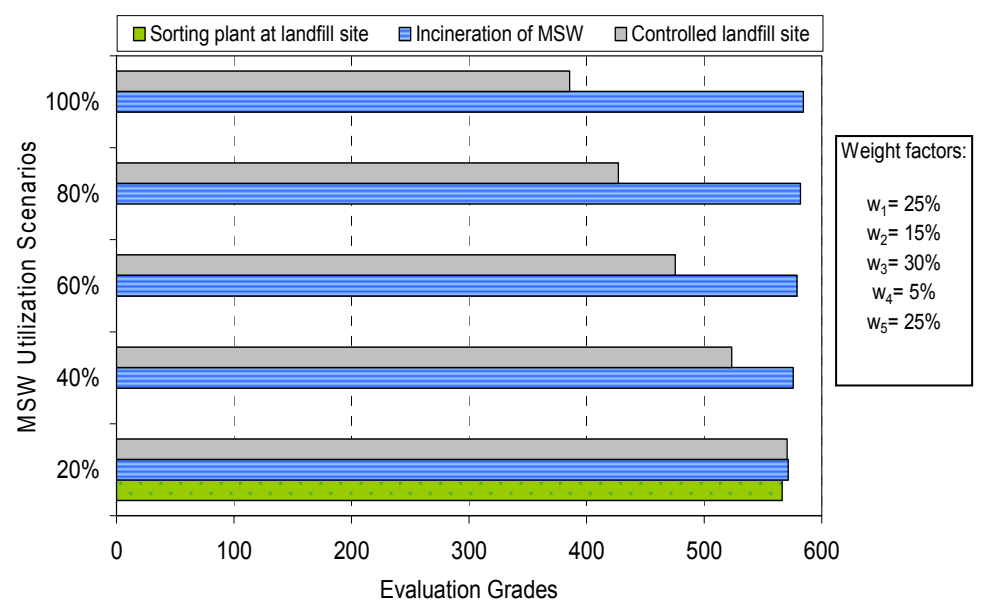

Figure 4. An alternative plan of energy recovery by MSW (for 2015 and BAU case)
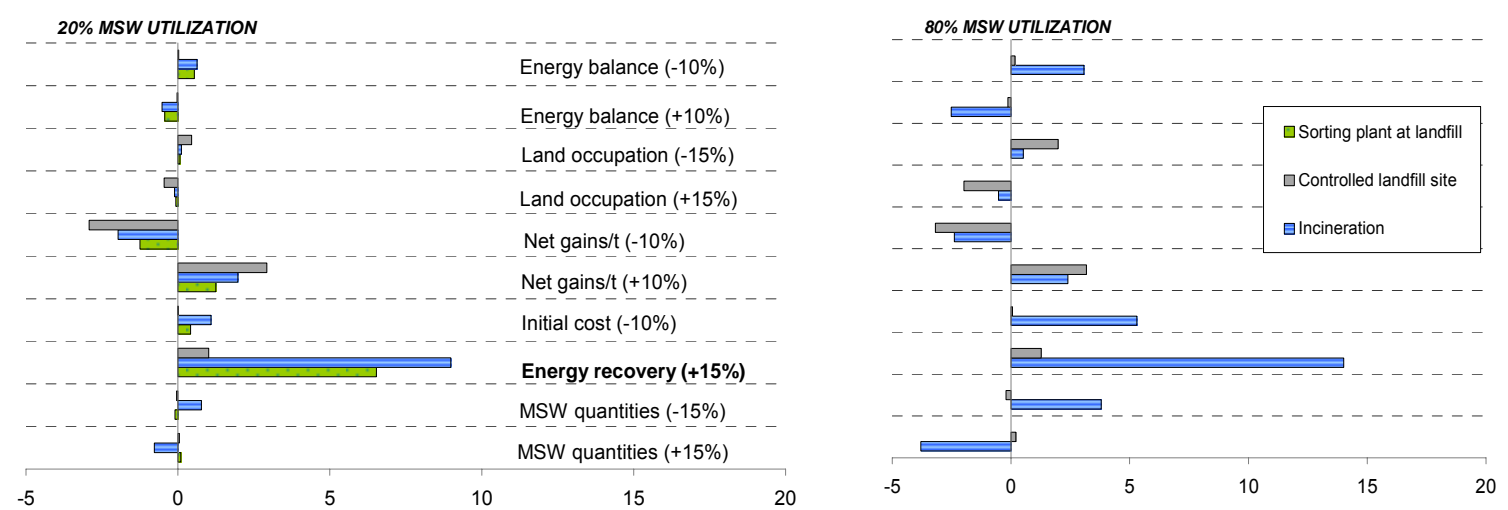

Figure 5. Effect of parameter values variation (\%) on the energy recovery methods' evaluation grades (for 2015 and BAU case)

\section{Sensitivity analysis based on the impact of the parameter values}

As indicated above, the results of the evaluation method followed in the present study are quite sensitive to any differentiation of the weight factor values and accordingly to the hierarchy of the main parameters involved. Nevertheless, at this point, it is worth mentioning that by varying the selected parameters values (see Table 1 ) by only 10-15 \%, significant fluctuations on the evaluation grades of each energy recovery method may arise as well, within an approximate range between $-5 \%$ and $+15 \%$ (Figure 5 ). For instance, a possible increment of the energy recovery of installations (i.e. a parameter which affects directly the assumed fossil fuel substitution and RES contribution percentages owed to the introduction of the energy recovery methods examined) in the examined regions in the order of $15 \%$ would increase the suitability (i.e. evaluation grades) of the "Incineration" method by almost $15 \%$ (using the reference weight factor values and the BAU case for 2015) at a waste utilization scenario of $80 \%$. Thus, that change would make the "Incineration" and the "Controlled landfill" almost equally competitive at lower MSW utilization scenarios regardless of the considerable difference in the initial cost between these two methods (Figure 6). Moreover, 
one could realize that the augmentative rate of installation's efficiency through the standardization of technologies applied would allow the partial replacement of urban landfills by small or medium size WTE plants.

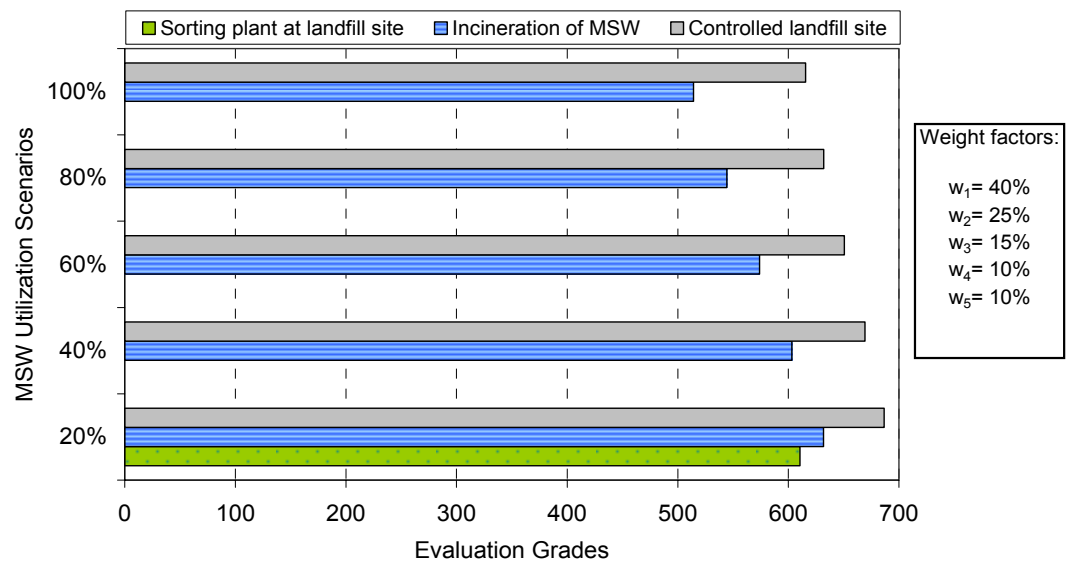

Figure 6. Evaluation of the three methods after varying the energy recovery parameter by $+15 \%$ (for 2015 and BAU case)

\section{CONCLUSIONS}

A detailed multi-criteria analysis was presented and applied for the evaluation of three energy recovery methods utilizing MSW in the Greek mainland and the island of Crete. The five waste utilization scenarios which were examined (between $20 \%$ and $100 \%$ ) revealed that the "Controlled landfill" is the most prevalent technology, while under certain circumstances (depending on the hierarchy of the criteria selected), the "Incineration" may be equally appropriate as well. Nevertheless, the presented quantitative evaluation method provides the ability for any alternative scenario to be performed through the diversification of its parameters hierarchy (i.e. initial capital investment, net gains per tonne of MSW treated, fossil fuel substitution in the national energy mix, contribution to the national RES target and land requirements) with respect to the local social needs. It should be mentioned that parameters which are not included in the present work such as "externalities" (i.e. any environmental, social, health, aesthetic, land cost, related to any activity relevant to the installation of the specific energy recovery plant as a direct or indirect effect) and "social approval" (i.e. the "Willing to Pay" or "Willing to Receive" costs for the acceptance or not of the energy recovery facilities by the local communities) give space for expanding the current work in the near future and thus enhancing the reliability of the findings.

\section{REFERENCES}

Chalvatzis K.J. and Hooper E. (2009) Energy security vs. climate change: Theoretical framework development and experience in selected EU electricity markets, Renew Sust Energ Rew, 13, 2703-2709.

Cheng $\mathrm{H}$. and $\mathrm{Hu}$ Y. (2010) Municipal solid waste (MSW) as a renewable source of energy: Current and future practices in China, J Bioresource Technology, 101, 3816-3824.

Cherubini F., Bargigli S. and Ulgiati S. (2009) Life cycle assessment (LCA) of waste management strategies: Landfilling, sorting plant and incineration, Energy, 34, 2116-2123.

Cherubini F., Bargigli S. and Ulgiati S. (2008) Life cycle assessment of urban waste management: Energy performances and environmental impacts. The case of Rome, Italy, Waste Manage., 28, 25522564.

Confederation of European Waste to Energy Plants (CEWEP) (2009). Available at: http://www.cewep.com/recycling/index.html (Accessed in May 2009).

Consogni S., Giugliano M. and Grosso M. (2005) Alternative strategies for energy recovery from municipal solid waste Part A: Mass and energy balances, Waste Manage., 25, 123-135.

Couth R., Davies J. and Howe A. (2003) Landfill financing and contracts, In: $9^{\text {th }}$ International Waste Management and Landfill Symposium, October 6-10, Cagliari, Italy. 
Department of Environmental, Food and Rural Affairs (Defra) (2009). Available at: www.defra.gov.uk (Accessed in June 2009).

Dolgen D., Sarptas H., Alpaslan N. and Kucukgul O. (2005) Energy potential of municipal solid wastes, Energ. Source, 27, 1483-1492.

Economopoulos A. (2009) Formulation and comparative evaluation of alternative plans for the management of municipal solid wastes in Greece, Department of Environmental Engineering, University of Crete.

Economopoulos A. (2007) Domestic waste management/national planning problems and rational solutions, Department of Environmental Engineering, University of Crete. (in Greek),

European Environment Agency (EEA) (2010) The European environment - state and outlook 2010. Available at: http://www.eea.europa.eu (Assessed in May 2011).

European Commission (EC) (2008) Waste Framework Directive 2008/98. Available at: http://eurlex.europa.eu/LexUriServ/LexUriServ.do?uri=OJ:L:2008:312:0003:0030:en:PDF (Assessed in June 2010).

Europe's Energy Portal (2010) Available at: http://www.energy.eu (Assessed in June 2010).

Eurostat (2009). European Statistics Agency. Available at: http://epp.eurostat.ec.europa.eu. (Accessed in June 2009)

Hellenic Solid Waste Management Association (HSWMA). (2010) Available at: http://www.eedsa.gr/ (Assessed in November 2010).

Kaldellis J.K., Mantelis N. and Zafirakis D. (2011) Evaluating the ability of Greek power stations to comply with the obligations posed by the Second National Allocation Plan concerning carbon dioxide emissions, Fuel, 90(9), 2884-2895.

Kaldellis J.K., Zafirakis D. and Kondili E. (2009) Contribution of lignite in the Greek electricity generation: Review and future prospects, Fuel, 88(3), 475-489.

Konstantinidis P., Giarikis Ath. and Kaldellis J.K. (2003) Evaluation of Domestic-Waste Collection System of Nikaia Municipality. Improvement Proposals, In: $8^{\text {th }}$ International Conference on Environmental Science and Technology, September 8-10, Univ. of Aegean, Global-NEST, Lemnos, Greece, 432-440.

Konstantinidis P., Skordilis A. and Kaldellis J.K. (2001) Recycling of Electric and Electronic Waste in Greece: Possibilities and Prospects, In: $7^{\text {th }}$ International Conf. on Environmental Science and Technology, Sept.3-6, Univ. of Aegean, Global-NEST, Syros, Greece, 460-469.

Konstantinidis P., Spiropoulos V., Vamvakis A. and Kaldellis J.K. (2000) Energy savings and cost reduction by recycling the demolition-construction debris, In: $5^{\text {th }}$ International Conference, Protection and Restoration of the Environment, July 1-4, Thassos, Greece, 869-878.

Mahar R.B., Yue D., Liu J., Zhang Y. and Nie Y. (2009) Biological pre-treatment of municipal solid waste prior to landfilling, Global NEST J., 11, 510-517.

Ministry of Environment, Energy and Climate Change (MINENV). (2010) 5th National Communication to the United Nations Framework Convection on Climate Change. Available at: http://unfccc.int/resource/docs/natc/grc nc5.pdf (Assessed in Nov. 2011).

Public Power Corporation (PPC) (2010) Selling prices of electricity for the interconnected system in Greece. Available at: http://www.dei.gr (Accessed in July 2010).

Sakkas Th., Kaldelli El., Murphy J.D. and Kaldellis J.K. (2005) Ethanol production for the Greek transportation sector using municipal solid wastes. Techno-economic and environmental analysis, In: ${ }^{\text {st }}$ National Conference of Chem. Eng. on "Alternative Fuels", Jan. 27-28, Athens, Greece (in Greek).

World Bank (2005) Pre-feasibility study for landfill gas recovery and utilization at Santa Tecla landfill Gravatai Brazil. Available at: http://www.bancomundial.org.ar/ (Assessed in November 2010). 